\title{
Symposium review: Macronutrient metabolism in the growing calf*
}

\section{W. J. J. Gerrits†}

Animal Nutrition Group, Wageningen University, PO Box 338, 6700 AH, Wageningen, the Netherlands

\begin{abstract}
Recent interest in increasing rates of body weight gain in heifer calves before weaning is based on the promise of an increase in milk production during first lactation. This increase is usually realized by increasing milk or milk replacer intake, delaying the onset of rumen development. Simultaneously feeding liquids and solid feeds brings about new challenges. Macronutrient metabolism in growing calves is reviewed, combining literature from heifer and veal calves with the objective to provide insights useful for developing novel feeding strategies. Growing calves are not efficiently retaining digested $\mathrm{N}$ when compared with other growing species. Energy and protein appear to be simultaneously limiting growth. With the possible exception of very young calves, low responses to incremental intakes of AA indicate that the limiting AA rarely explains the low efficiency of $\mathrm{N}$ utilization. Nonetheless, there are indications that disproportionate oxidation of $\mathrm{AA}$ as a result of AA imbalance may occur, notably in splanchnic tissues. Long-chain fatty acids, absorbed from the milk or calf milk replacer (CMR) are preferentially deposited as body fat, but this strongly depends on the need for ATP, fueled by the oxidation of carbohydrates. Hence, fatty acid oxidation typically decreases with an increased feeding level. Insulin sensitivity in calves is quite high at birth, but decreases independent of feeding strategy in early age to very low levels when compared with other species. Even though changes in insulin sensitivity may be provoked by early life nutrition, these effects are small and rather transient. In heavy calves, insulin sensitivity is invariably low. Large effects of dietary treatments on postprandial glucose and insulin responses, as often observed, are unlikely to be caused by differences in insulin sensitivity. Unlike in pigs, de novo fatty acid synthesis is not a significant
\end{abstract}

Received June 22, 2018

Accepted September 19, 2018.

*Presented as part of the Growth and Development/Ruminant Nutrition Symposium: Postweaning and Beyond at the ADSA Annual Meeting, Knoxville, Tennessee, June 2018.

†Corresponding author: walter.gerrits@wur.nl route of disposal of glucose absorbed from the intestinal tract. Instead, high lactate fluxes in milk-fed calves suggest this may be an important route of disposal. When combining the feeding of milk or CMR with solid feeds, estimation of the contribution of the individual ration components is difficult, and interactions inside the gastrointestinal tract complicate the estimation of their feeding value. There are indications in veal calves that use of nutrients absorbed from a CMR is not dependent on the level of intake of solid feeds.

Key words: calf, nutrient utilization, glucose metabolism, amino acid utilization, milk replacer

\section{INTRODUCTION}

Recent interest in increasing rates of $\mathrm{BW}$ gain in heifer calves before weaning is based on the promise of an increase in milk production during first lactation. Even though a recent meta-analysis revealed that variation in preweaning ADG explained less than $3 \%$ of the variation, an increase of $100 \mathrm{~g} / \mathrm{d}$ in liquid DMI in calves with an ADG exceeding $500 \mathrm{~g} / \mathrm{d}$ could increase first-lactation milk production by $66 \mathrm{~kg}$, which could be doubled when combined with increased starter intake (Gelsinger et al., 2016). In veal production, high rates of BW gain are typically achieved. From both a welfare and economic perspective, there is a strong incentive to replace a considerable portion of the calf milk replacer (CMR) by solid feeds (SF) in the diet (e.g., Webb et al., 2015), and feeding schedules in which $50 \%$ of the energy intake originates from SF are no exception anymore. In heifers, developing feeding strategies to achieve high rates of ADG deserves attention, as increasing DMI without considering its composition ignores the altered contribution of maintenance requirements of protein and energy but also of minerals to total requirements. Simultaneous feeding of milk or CMR and SF brings about new challenges. First, an increase in CMR intake generally reduces the intake of starter grains (Yunta et al., 2015; Gelsinger et al., 2016). In addition, several possible interactions between CMR and SF influence the nutritional value of these ration components. Most of these interactions occur in the gastrointestinal tract, starting at the onset 
of rumen development, and include recycling of urea originating from AA from the CMR (Berends et al., 2014b), milk leakage into the rumen (Labussière et al., 2014), influences of SF on passage rate kinetics of the liquid or vice versa (Berends et al., 2015b). Despite all of these possible interactions, the vast majority of macronutrients not retained in the body are lost during postabsorptive metabolism. The priorities of the calf for retaining or oxidizing macronutrients are believed to depend on intake, within bounds of priorities or capacities determined by evolution. This manuscript reviews macronutrient metabolism in growing calves, combining literature from heifer and veal calves with the objective to provide insights useful for developing novel feeding strategies.

\section{PROTEIN}

In milk-fed calves, utilization of digested $\mathrm{N}$ for $\mathrm{N}$ retention is typically around $70 \%$ and decreases with increasing $\mathrm{BW}$ below $50 \%$ when $\mathrm{BW}$ increases above $150 \mathrm{~kg}$ (Figure 1). It should be noted that the between study variation is substantial. These values correspond with the meta-analysis by Zanton and Heinrichs (2008), stating that for milk-fed heifer calves, between 40 and
$50 \%$ of ingested $\mathrm{N}$ was retained, corresponding to a utilization of digested $\mathrm{N}$ for $\mathrm{N}$ retention between 50 and $60 \%$ in the young calves included in their analysis. Incremental efficiencies of $\mathrm{N}$ retention, however, are lower and drop from 50 to $65 \%$ at BW below $70 \mathrm{~kg}$ (Donnelly and Hutton, 1976; Blome et al., 2003; Labussiere et al., 2008) to values between 20 and $40 \%$ at BW above 150 $\mathrm{kg}$ of BW (Gerrits et al., 1996; Labussiere et al., 2008). Occurrence of urea recycling and difficulties predicting postruminal $\mathrm{N}$ digestion complicate the analogy with weaned calves, but it is expected that the incremental efficiencies measured in calves fed milk or CMR represent an upper limit to the range to be achieved in weaned calves. The incremental efficiency for using nitrogen for deposition is much lower than for that of other growing farm-animal species. The reasons for the apparent low priority of calves to deposit AA that are absorbed from the intestinal tract can be manifold, and some have been extensively discussed by van den Borne et al. (2006a).

\section{Protein and Energy Dependent Phases}

Extra energy absorbed from the gastrointestinal tract has been demonstrated to increase $\mathrm{N}$ efficiency,

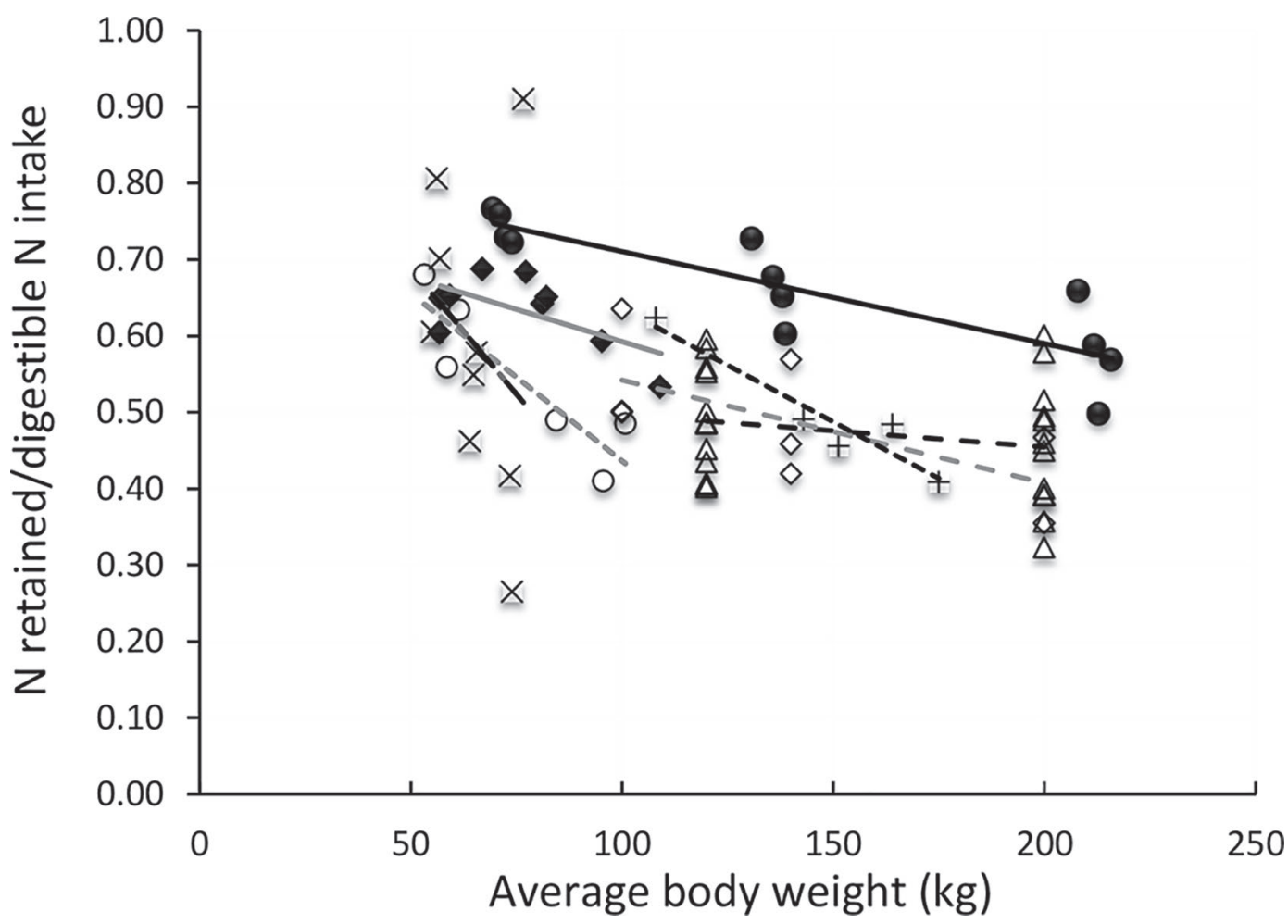

Figure 1. Efficiency of utilization of digested $\mathrm{N}$ for $\mathrm{N}$ retention in calves with increasing BW. All data selected are of calves fed exclusively on milk replacer containing dairy proteins as the only protein source. Data from $\bigcirc$ Roy et al. (1970), $\Delta$ Gerrits et al. (1996), $\bullet$ Labussiere et al. (2008), $\times$ Diaz et al. (2001), $\diamond$ Van der Togt and Gerrits (1998), $\diamond$ unpublished, and + van den Borne et al. (2006b). 
regardless the level of $\mathrm{N}$ intake (Gerrits et al., 1996; Zanton and Heinrichs, 2008; Berends et al., 2012). This indicates that the concept of protein and energy dependent phases, commonly used in pigs (Whittemore and Fawcett, 1976; Halas et al., 2018) and broilers (Eits et al., 2002) does not hold for calves, and hence, energy and protein are always simultaneously limiting. This was nicely demonstrated in steers, where abomasal infusion of methionine or energy from various sources independently increased $\mathrm{N}$ efficiency regardless of the source of energy infused (Schroeder et al., 2006). This likely connects to the low incremental $\mathrm{N}$ efficiency, as also in pigs, it has been demonstrated that incremental $\mathrm{N}$ efficiency drops with age, and distinct protein and energy dependent phases have been shown to be more difficult to detect in older pigs. It is likely that the extent to which protein and energy limit the rate of BW gain depends on BW, consistent with the drop in $\mathrm{N}$ efficiency with age.

\section{Limiting Amino Acids}

In any of the studies reported in Figure 1, the low efficiency of $\mathrm{N}$ utilization could have been caused by one or more AA, limiting the rate of protein deposition. In milk-fed calves above $100 \mathrm{~kg}$ of BW, the incremental efficiency of all AA for deposition in the body was analyzed in 2 experiments in which protein intake varied over a wide range. It was based on the idea that the incremental efficiency of at least one indispensable AA would be higher than the reported incremental efficiency of $30 \%$ for total protein (Gerrits et al., 1996). The incremental efficiencies reported varied within a rather narrow range of 11 to $29 \%$ for all indispensable AA (Gerrits et al., 1998), but were higher for the conditionally essential arginine and cystine. It was concluded that single limiting AA are not the cause for the low incremental efficiency of $\mathrm{N}$ utilization. This corresponds to the observations by Batista et al. (2016) in steers, who found the incremental response of $\mathrm{N}$ retention to abomasal infused lysine to be close to $40 \%$ in the presence of an excess of all other EAA, co-infused into the abomasum. For young calves, this may be different, as significant improvement of ADG has been reported after addition of single AA in young calves [e.g., addition of lysine in the first experiment reported by Hill et al. (2008) and methionine by Chagas et al. (2018)]. It is notoriously difficult to prepare a CMR severely deficient in a single AA for the study of incremental responses. Even in calves below $6 \mathrm{wk}$ of age, responses of ADG have been demonstrated low or absent [experiments 2 and 3 for methionine, and 4 for threonine (Hill et al., 2008); methionine (Castro et al., 2016); and isoleucine+threonine (Morrison et al., 2017)]. When crudely estimating the incremental efficiency of utilization of the added AA in these studies from responses in ADG, assuming a fixed concentration of each AA in ADG (Gerrits et al., 1998), these appear to be below $30 \%$ for methionine [experiment 2 and 3 from Hill et al. (2008), Castro et al. (2016), Chagas et al. (2018), threonine in experiment 4 from Hill et al. (2008), and around 40\% for isoleucine when including $10 \%$ of plasma protein (Morrison et al., 2017)]. The incremental response to lysine in the first experiment by Hill et al. (2008) was exceptionally high (i.e., $80 \%$ for the lowest $2 \mathrm{CP}$ diets).

Asynchronous absorption of AA and glucose has been demonstrated to increase body fat deposition in heavy milk-fed calves, leaving $\mathrm{N}$ efficiency virtually unaffected (van den Borne et al., 2006c). However, asynchronous supplementation of lysine and threonine in a CMR in which about $75 \%$ of the protein originated from soluble wheat protein was found to reduce $\mathrm{N}$ efficiency from 46 to $35 \%$. Interestingly, when the asynchronous absorption was corrected for by intravenous infusion of lysine and threonine, the increase in $\mathrm{N}$ retention was markedly lower compared with enteral supplementation (van den Borne et al., 2012). They concluded that an AA imbalance in the splanchnic tissues may result in disproportionate AA oxidation.

\section{Urea Recycling}

Recycling of urea has been demonstrated and measured in ruminants (Sarraseca et al., 1998). It is commonly assumed to be triggered by low $\mathrm{N}$ concentrations in the rumen, but it cannot be excluded that the availability of urea in the circulation affects urea recycling. The influence of dietary $\mathrm{CP}$ content on urea recycling has been recently reviewed in cattle (Batista et al., 2017). In milk-fed calves, urea production is high and largely originating from milk AA. In a study combining MR with low-protein SF, Berends et al. (2014b) demonstrated, using a $\left[{ }^{15} \mathrm{~N}_{2}\right]$ urea approach, that for every incremental gram of DM from SF intake, nitrogen intake increased by $0.70 \mathrm{~g}$, and nitrogen retention increased by $0.55 \mathrm{~g}(P<0.01)$. Of this increase in nitrogen retention, $19 \%$ could be directly explained by urea recycling, with the remaining part being explained by increased intake of $\mathrm{N}$ via the $\mathrm{SF}$, and an increased $\mathrm{N}$ efficiency related to increased ME intake. In a followup study, it was demonstrated that the contribution of urea recycling to the nitrogen economy of veal calves was substantially lower when a high-protein concentrate was fed (Berends et al., 2015a). It was concluded that low $\mathrm{N}$ availability in the rumen limits microbial growth 
and rumen fermentation in calves fed low-N SF (93 g of $\mathrm{CP} / \mathrm{kg}$ of $\mathrm{DM})$, and this effect cannot be compensated for by recycling of urea originating from AA absorbed from a CMR.

In summary, growing calves are not efficiently retaining digested N. Energy and protein appear to be simultaneously limiting growth. With the possible exception of very young calves, low responses to incremental intakes of AA indicate that the limiting AA rarely explains the low efficiency of $\mathrm{N}$ utilization. Nonetheless, there are indications that disproportionate oxidation of $\mathrm{AA}$ as a result of AA imbalance may occur, notably in splanchnic tissues.

\section{FATS AND CARBOHYDRATES}

The capacity of young calves to digest lactose has been demonstrated to be high (Huber et al., 1964) and remains high when continued to be exposed to lactose (Gilbert et al., 2015a). Starch seems a rather poor source of glucose for calves. In milk-fed calves, Gilbert et al. (2015a) demonstrated maltase activity to hamper the conversion of starch to glucose, estimating starch fermentation to account for $90 \%$ of the starch ingested, and rather independent of the level of starch intake (Gilbert et al., 2015b). The capacity of calves to digest long-chain fatty acids is high and strongly dependent on emulsifying properties, as reviewed by Kertz et al. (2017). Both long-chain fatty acids and glucose are important energy sources as long as calves are fed milk or CMR. Typically, oxidation of long-chain fatty acids depends on the level of feed intake. van den Borne (2006b) demonstrated in veal calves that the proportion of dietary fatty acids oxidized dropped from nearly $80 \%$ to about 30\% when feed intake increased from 1.5 to 2.5 the ME requirements for maintenance. Carbohydrate oxidation remained above $90 \%$ of intake. Following the observation that $80 \%$ of the ${ }^{13} \mathrm{C}$ from orally supplied $\left[\mathrm{U}_{-}{ }^{13} \mathrm{C}\right]$ glucose was recovered as ${ }^{13} \mathrm{CO}_{2}$, and similar recoveries were obtained after feeding $\left[2-{ }^{13} \mathrm{C}\right]$ glucose, van den Borne et al. (2007) concluded that de novo synthesis of fatty acids is not a major route of disposal of absorbed glucose in calves. It follows that calves will deposit more fat when increasing glucose absorption, but that this almost exclusively originates from sparing fatty acids from oxidation.

\section{GLUCOSE METABOLISM AND INSULIN SENSITIVITY}

With rapidly increasing milk or CMR intake after birth, lactose becomes the dominant source for ATP production in calves. With prolonged high intake, however, as common in veal production, problems arise maintaining glucose homeostasis. These problems were already demonstrated in the previous century (Doppenberg and Palmquist, 1991; Hugi et al., 1997, 1998), influenced by, for example, age, level of feeding of the CMR, and feeding frequency (Hugi et al., 1997; Vicari et al., 2008a); nutrient synchrony (Vicari et al., 2008b); and protein intake (Gerrits et al., 2008). These problems are characterized by hyperglycemia, hyperinsulinemia, and glucosuria and are connected to a low insulin sensitivity (Hugi et al., 1998). Insulin sensitivity in calves rapidly drops with age. Stanley et al. (2002), found 10- to 20-fold higher insulin sensitivities in Holstein and Jersey calves at 4 to 5 wk of age $[15$ and $25 \times$ $10^{-4}(\mathrm{mU} / \mathrm{L})^{-1} \times \mathrm{min}^{-1}$, respectively], than Pantophlet et al. (2016c) in Holstein calves of about $190 \mathrm{~kg}$ of BW, both using the frequently sampled intravenous glucose tolerance test (FSIGT). Recent developments in feeding strategies of heifer calves have renewed interest in manipulating insulin sensitivity in early life, based on the promise of improved performance and milk production in later life. Although, clearly, postprandial glucose and insulin kinetics are influenced by intake of milk or CMR, evidence is accumulating that these changes are rather unrelated to changes in insulin sensitivity. In young calves, MacPherson et al. (2016) found no effect of doubling CMR intake from 4 to $8 \mathrm{~L} / \mathrm{d}$ on glucose an insulin responses to a FSIGT, hence concluding that its effect on insulin sensitivity was minimal. Yunta et al. (2015) observed a tendency for a decrease in insulin sensitivity with increasing CMR intake, particularly at $42 \mathrm{~d}$ of age. It should be noted that the FSIGT test was performed only after a 5 -h fasting period, at which point both glucose and insulin concentrations may still have been elevated. Recently, it was demonstrated that in calves, insulin sensitivity decreases rapidly, by almost $70 \%$, between wk 3 and 6 of age, unaffected by weaning (Pantophlet et al., 2016b). It seems therefore that insulin sensitivity in calves is quite high at birth, and decreases independent of feeding strategy in early age to very low levels when compared with other species. In agreement, Kesser et al. (2017) recently concluded that even though slight changes in insulin sensitivity may be provoked by early life nutrition, these effects are rather transient and they found no evidence for sustained effects. In heavy calves, insulin sensitivity is invariably low, being rather insensitive to the carbohydrate source in the CMR (Pantophlet et al., 2016c) or to an exchange of lactose for fat (euglycemic-hyperinsulinemic clamp; Pantophlet et al., 2016a). Large effects of dietary treatments on postprandial glucose and insulin responses, as often observed (e.g., Vicari et al., 2008a,b), are therefore unlikely to be caused by differences in insulin sensitivity. Pantophlet et al. 
(2016b) speculated that the role of insulin-independent glucose transporters such as GLUT-1 may become relatively more important with age. Indeed, despite the low insulin sensitivity in heavy calves, glucose is virtually completely oxidized, regardless of the level of feeding (van den Borne et al., 2007). In addition, insulin peaks in calves typically follow, rather than precede glucose peaks postprandially (Vicari et al., 2008b), even in young calves (MacPherson et al., 2016; Pantophlet et al., 2016b), which differs from responses in other species and illustrates the absence of cephalic responses to a meal. Hence, insulin sensitivity appears not to be a promising target for early life metabolic programming in calves.

Following the observation that calves oxidize the vast majority of the lactose ingested, it appears that indeed the glucose is transported into the cells. Glucose concentrations often exceed the renal threshold and urinary glucose excretion is commonly observed in heavy veal calves (Hugi et al., 1997; van den Borne et al., 2006b; Gerrits et al., 2008). Nonetheless, the quantity of glucose excreted via urine rarely exceeds $5 \%$ of the daily lactose intake and cannot be regarded a major route of glucose disposal. Unlike other farm-animal species such as pigs and broiler chickens, de novo fatty acid synthesis from glucose is not a significant route of disposal for glucose in calves, as discussed above. Recent unpublished data in our laboratory indicate that in milk-fed calves of about $190 \mathrm{~kg}$ of BW, postprandial fluxes of lactate (i.e., between 2 and $4 \mathrm{~h}$ after a CMR meal), measured by dilution of a primed, continuous intravenous infusion of $\left[1-{ }^{13} \mathrm{C}\right]$ lactate and $\left[\mathrm{U}-{ }^{13} \mathrm{C}\right]$ lactate were on average $150 \mathrm{~g} / \mathrm{h}$, which was higher than the glucose flux $(70 \mathrm{~g} / \mathrm{h})$, measured during the same time period by dilution of a primed, continuous intravenous infusion of $\left[2-{ }^{13} \mathrm{C}\right]$ glucose and $\left[\mathrm{U}_{-}{ }^{13} \mathrm{C}\right]$ glucose. Isotopic enrichment of lactate and glucose were measured as lactate $\mathrm{M}+1$, lactate $\mathrm{M}+3$, glucose $\mathrm{M}+1$, and glucose $\mathrm{M}+6$ in plasma. These data indicate that the major portion of glucose and galactose is rapidly converted into lactate during peak absorption. In summary, in heavy milk-fed calves, due to the low insulin sensitivity, substantial quantities of glucose remain in the circulation for 2 to $6 \mathrm{~h}$ after a CMR meal. Only a negligible portion is used for fatty acid synthesis, and quite likely, a major part is converted to lactate for later oxidation. To what extent these mechanisms operate in young calves remains to be elucidated, but the rapid drop in insulin sensitivity after birth suggests the lactate route may play a significant role in young calves as well. It should be noted that ad libitum availability of milk directly after birth may influence the role of lactate, as suggested by the absence of an increase (Schäff et al.,
2016) or even a decrease (Frieten et al., 2017) in plasma lactate concentration in intensively milk-fed when compared with restrictedly milk-fed calves.

\section{NUTRIENTS FROM RUMEN FERMENTATION}

Rumen development is initiated upon the consumption of SF, triggering the production of VFA. The importance of the composition of the SF, in particular the presence of coarse particles via the roughage portion of the SF fraction has been recently reviewed by Khan et al. (2016). In addition, the influence of physical form of starters has been undervalued (Kertz, 2017). The increase in SF intake with age, and thus the increasing importance of VFA in the metabolism of calves is obvious, although weaning strategies differ and the extent to which the roughage portion of the SF component depresses SF intake has been debated (Khan et al., 2016).

Evaluation of the contribution of SF to the nutrient requirement of calves is complicated by the simultaneous provision of milk or CMR and SF. At the level of digestion, it is difficult to separate the contribution of the CMR to ileal or fecal excretion. When feeding incremental quantities of SF at a fixed level of feeding of CMR, Berends et al. (2012) demonstrated the apparent total-tract digestibility of a SF mixture of concentrates, straw, and corn silage (50:25:25 on a DM basis) to be 64 and $60 \%$ for DM and energy in calves in a BW range of 108 to $164 \mathrm{~kg}$. Notably, the total-tract digestibility of NDF increased significantly with BW from 46 at $108 \mathrm{~kg}$ of BW to $56 \%$ at $164 \mathrm{~kg}$ of BW. This increase in digestion efficiency with age or BW was later also demonstrated by Berends et al. (2014a).

When exchanging substantial quantities of CMR for SF components during the weaning transition or during prolonged feeding of CMR as common in veal calves, the experimental design used to estimate the feeding value for these ration components becomes critical. When the studies are conducted over a large age or weight range of the calves, differences in BW between treatments may become problematic. Attempts to exchange SF for CMR, maintaining energy (or protein) intake, are problematic when the digestibility, metabolizability, or net energy values are not known. Quite often these are the subject of study. To this end, we used a paired-gain approach to study the feeding value of 2 mixtures of SF with a roughage:concentrate ratio of 50:50 or 20:80 on a DM basis (Berends et al., 2014a). Dry matter intake from SF was targeted to reach 20, 100,180 , and $260 \mathrm{~kg}$ of DM for $4 \mathrm{SF}$ levels, respectively, during the 16-wk experimental period, and increased with preplanned, equal weekly increments. The quantity of CMR provided was adjusted every 2 wk based 
on BW to achieve similar targeted rates of carcass gain across treatments. The reduction in CMR provided (in $\mathrm{kg}$ of DM) to realize equal rates of gain with inclusion of SF (in $\mathrm{kg}$ of $\mathrm{DM}$ ) was considered to represent the feeding value of the SF mixture relative to the CMR. The feeding value of the 20:80 SF mixture was found to be 10\% higher compared with that of the 50:50 SF mixture. The feeding value of SF relative to that of MR also increased substantially with age. This approach is suitable for estimating the nutritional value of the $\mathrm{SF}$ component relative to that of a CMR, typically studied over a large age or weight range. For this reason, this approach is less suited to study feeding strategies around the weaning transition.

The end products of fermentation, absorbed from the (developing) rumen of young calves, can be easily metabolized in a way comparable to that of a functional ruminant. As long as milk or CMR and SF are fed simultaneously (i.e., before the weaning transition or prolonged as commonly done in veal production), it is unknown to what extent interactions between nutrients absorbed from the rumen or from intestinal digestion of milk or CMR occur. Unpublished data from our laboratory in calves of 125 to $250 \mathrm{~kg}$ of BW indicate identical responses of energy and nitrogen retention to incremental intakes of protein, fat, and lactose from a CMR between calves fed 15 or $40 \%$ of the gross energy intake from $\mathrm{SF}$ in a paired-gain setting. No interactions were found between the nutrient added via the CMR and the level of SF feeding. Incremental efficiencies of fat and lactose for energy gain were both $70 \%$, and for protein it was $40 \%$, independent of the level of SF feeding. This indicates that nutrients absorbed from rumen fermentation and from intestinal CMR digestion may be used in an additive manner. Whether this is the also the case in young calves remains to be determined.

\section{OUTLOOK}

Combining data from heifer and veal calf studies provides a unique opportunity to characterize the potential of calves in terms of macronutrient utilization, providing interesting leads for adapting feeding strategies to altered objectives, for example, increasing preweaning BW gain or reducing environmental nutrient losses. The efficiency of utilizing dietary proteins for BW gain rapidly decreases with age, rather independent of dietary AA composition, emphasizing the importance of adapting dietary protein concentrations with progressing age. It is important to acknowledge that energy absorbed from the intestinal tract can contribute to further improving protein efficiency. Whereas dietary carbohydrates absorbed from a CMR will be almost exclusively used as a fuel, dietary fat can also be deposited as body fat. A strong reduction of insulin sensitivity occurs in early life, independent of diet composition. Although this leads to a shift in the type of substrate available, it does not prevent oxidative carbohydrate metabolism. The concept of additivity of nutrients absorbed from rumen fermentation and from CMR needs further exploration when simultaneously feeding $\mathrm{SF}$ and CMR.

\section{REFERENCES}

Batista, E. D., E. Detmann, S. C. Valadares Filho, E. C. Titgemeyer, and R. F. D. Valadares. 2017. The effect of CP concentration in the diet on urea kinetics and microbial usage of recycled urea in cattle: A meta-analysis. Animal 11:1303-1311.

Batista, E. D., A. H. Hussein, E. Detmann, M. D. Miesner, and C. Titgemeyer. 2016. Efficiency of lysine utilization by growing steers. J. Anim. Sci. 94:648-655.

Berends, H., J. J. G. C. van den Borne, S. J. J. Alferink, C. G. van Reenen, E. A. M. Bokkers, and W. J. J. Gerrits. 2012. Low-protein solid feed improves the utilization of milk replacer for protein gain in veal calves. J. Dairy Sci. 95:6654-6664.

Berends, H., J. J. G. C. van den Borne, H. Mollenhorst, C. G. van Reenen, E. A. M. Bokkers, and W. J. J. Gerrits. 2014a. Utilization of roughages and concentrates relative to that of milk replacer increases strongly with age in veal calves. J. Dairy Sci. 97:6475-6484.

Berends, H., J. J. G. C. van den Borne, B. A. Røjen, W. H. Hendriks, and W. J. J. Gerrits. 2015a. Effect of protein provision via milk replacer or solid feed on protein metabolism in veal calves. J. Dairy Sci. 98:1119-1126.

Berends, H., J. J. G. C. van den Borne, B. A. Røjen, J. van Baal, and W. J. J. Gerrits. 2014b. Urea recycling contributes to nitrogen retention in calves fed milk replacer and low-protein solid feed. J. Nutr. 144:1043-1049.

Berends, H., J. J. G. C. van den Borne, N. Stockhofe-Zurwieden, M. S. Gilbert, T. Zandstra, W. F. Pellikaan, C. G. van Reenen, E. A. M. Bokkers, and W. J. J. Gerrits. 2015b. Effect of solid feed level and roughage-to-concentrate ratio on ruminal drinking and passage kinetics of concentrate, straw, and milk replacer in veal calves. J. Dairy Sci. 98:5621-5629.

Blome, R. M., J. K. Drackley, F. K. McKeith, M. F. Hutjens, and G. C. McCoy. 2003. Growth, nutrient utilization, and body composition of dairy calves fed milk replacers containing different amounts of protein. J. Anim. Sci. 81:1641-1655.

Castro, J. J., G. H. Hwang, A. Saito, D. A. Vermeire, and J. K. Drackley. 2016. Assessment of the effect of methionine supplementation and inclusion of hydrolyzed wheat protein in milk proteinbased milk replacers on the performance of intensively fed Holstein calves. J. Dairy Sci. 99:6324-6333.

Chagas, J. C. C., M. A. Ferreira, A. P. Faciola, F. S. Machado, M. M. Campos, M. R. Entjes, J. L. Donzele, and M. I. Marcondes. 2018. Effects of methionine plus cysteine inclusion on performance and body composition of liquid-fed crossbred calves fed a commercial milk replacer and no starter feed. J. Dairy Sci. 101:6055-6065.

Diaz, M. C., M. E. Van Amburgh, J. M. Smith, J. M. Kelsey, and E. L. Hutten. 2001. Composition of growth of Holstein calves fed milk replacer from birth to 105-kilogram body weight. J. Dairy Sci. 84:830-842.

Donnelly, P. E., and J. B. Hutton. 1976. Effects of dietary protein and energy on the growth of Friesian hull calves: I. Food intake, growth, and protein requirements. N. Z. J. Agric. Res. 19:289-297.

Doppenberg, J., and D. L. Palmquist. 1991. Effect of dietary fat level on feed intake, growth, plasma metabolites and hormones of calves fed dry or liquid diets. Livest. Prod. Sci. 29:151-166. 
Eits, R. M., R. P. Kwakkel, M. W. A. Verstegen, P. Stoutjesdijk, and K. H. d. Greef. 2002. Protein and lipid deposition rates in male broiler chickens: Separate responses to amino acids and proteinfree energy. Poult. Sci. 81:472-480.

Frieten, D., C. Gerbert, C. Koch, G. Dusel, K. Eder, E. Kanitz, J. M. Weitzel, and H. M. Hammon. 2017. Ad libitum milk replacer feeding, but not butyrate supplementation, affects growth performance as well as metabolic and endocrine traits in Holstein calves. J. Dairy Sci. 100:6648-6661.

Gelsinger, S. L., A. J. Heinrichs, and C. M. Jones. 2016. A metaanalysis of the effects of preweaned calf nutrition and growth on first-lactation performance. J. Dairy Sci. 99:6206-6214.

Gerrits, W. J. J., J. W. Schrama, and S. Tamminga. 1998. The marginal efficiency of utilization of all ileal digestible indispensable amino acids for protein gain is lower than $30 \%$ in preruminant calves between 80 and $240 \mathrm{~kg}$ live weight. J. Nutr. 128:1774-1785.

Gerrits, W. J. J., G. H. Tolman, J. W. Schrama, S. Tamminga, M. W. Bosch, and M. W. A. Verstegen. 1996. Effect of protein and protein-free energy intake on protein and fat deposition rates in preruminant calves of 80 to $240 \mathrm{~kg}$ live weight. J. Anim. Sci. 74:2129-2139.

Gerrits, W. J. J., J. J. G. C. van den Borne, and J. W. Blum. 2008. Low-dietary protein intake induces problems with glucose homeostasis and results in hepatic steatosis in heavy milk-fed calves. Domest. Anim. Endocr. 35:121-129.

Gilbert, M. S., A. J. Pantophlet, H. Berends, A. M. Pluschke, J. J. G. C. van den Borne, W. H. Hendriks, H. A. Schols, and W. J. J. Gerrits. 2015a. Fermentation in the small intestine contributes substantially to intestinal starch disappearance in calves. J. Nutr. 145:1147-1155.

Gilbert, M. S., J. J. G. C. van den Borne, H. Berends, A. J. Pantophlet, H. A. Schols, and W. J. J. Gerrits. 2015b. A titration approach to identify the capacity for starch digestion in milk-fed calves. Animal 9:249-257.

Halas, V., W. J. J. Gerrits, and J. Van Milgen. 2018. Models of feed utilization and growth in monogastric animals. Chapter 14 in Feed Evaluation Science. Wageningen Academic Publishers, Wageningen, the Netherlands.

Hill, T. M., H. G. Bateman Ii, J. M. Aldrich, R. L. Schlotterbeck, and K. G. Tanan. 2008. Optimal concentrations of lysine, methionine, and threonine in milk replacers for calves less than five weeks of age. J. Dairy Sci. 91:2433-2442.

Huber, J. T., R. J. Rifkin, and J. M. Keith. 1964. Effect of level of lactose upon lactase concentrations in the small intestines of young calves. J. Dairy Sci. 47:789-792.

Hugi, D., R. M. Bruckmaier, and J. W. Blum. 1997. Insulin resistance, hyperglycemia, glucosuria, and galactosuria in intensively milk-fed calves: Dependency on age and effects of high lactose intake. J. Anim. Sci. 75:469-482.

Hugi, D., L. Tappy, H. Sauerwein, R. M. Bruckmaier, and J. W. Blum. 1998. Insulin-dependent glucose utilization in intensively milk-fed veal calves is modulated by supplemental lactose in an age-dependent manner. J. Nutr. 128:1023-1030.

Kertz, A. F. 2017. Letter to the Editor: A call for more complete reporting and evaluation of experimental methods, physical forms of starters, and results in calf research. J. Dairy Sci. 100:851-852.

Kertz, A. F., T. M. Hill, J. D. Quigley III, A. J. Heinrichs, J. G. Linn, and J. K. Drackley. 2017. A 100-Year Review: Calf nutrition and management. J. Dairy Sci. 100:10151-10172.

Kesser, J., M. Korst, C. Koch, F. J. Romberg, J. Rehage, U. Müller, M. Schmicke, K. Eder, H. M. Hammon, H. Sadri, and H. Sauerwein. 2017. Different milk feeding intensities during the first 4 weeks of rearing dairy calves: Part 2: Effects on the metabolic and endocrine status during calfhood and around the first lactation. J. Dairy Sci. 100:3109-3125.

Khan, M. A., A. Bach, D. M. Weary, and M. A. G. von Keyserlingk. 2016. Invited review: Transitioning from milk to solid feed in dairy heifers. J. Dairy Sci. 99:885-902.

Labussière, E., H. Berends, M. S. Gilbert, J. J. G. C. van den Borne, and W. J. J. Gerrits. 2014. Estimation of milk leakage into the ru- men of milk-fed calves through an indirect and repeatable method. Animal 8:1643-1652.

Labussiere, E., S. Dubois, J. Van Milgen, G. Bertrand, and J. Noblet. 2008. Effects of dietary crude protein on protein and fat deposition in milk-fed veal calves. J. Dairy Sci. 91:4741-4754.

MacPherson, J. A. R., H. Berends, L. N. Leal, J. P. Cant, J. MartínTereso, and M. A. Steele. 2016. Effect of plane of milk replacer intake and age on glucose and insulin kinetics and abomasal emptying in female Holstein Friesian dairy calves fed twice daily. J. Dairy Sci. 99:8007-8017.

Morrison, S. Y., J. M. Campbell, and J. K. Drackley. 2017. Amino acid supplementation of calf milk replacers containing plasma protein. J. Dairy Sci. 100:4637-4649.

Pantophlet, A. J., W. J. J. Gerrits, R. J. Vonk, and J. J. G. C. van den Borne. 2016a. Substantial replacement of lactose with fat in a high-lactose milk replacer diet increases liver fat accumulation but does not affect insulin sensitivity in veal calves. J. Dairy Sci. 99:10022-10032.

Pantophlet, A. J., M. S. Gilbert, J. J. G. C. van den Borne, W. J. J. Gerrits, M. G. Priebe, and R. J. Vonk. 2016b. Insulin sensitivity in calves decreases substantially during the first 3 months of life and is unaffected by weaning or fructo-oligosaccharide supplementation. J. Dairy Sci. 99:7602-7611.

Pantophlet, A. J., M. S. Gilbert, J. J. G. C. van den Borne, W. J. J. Gerrits, H. Roelofsen, M. G. Priebe, and R. J. Vonk. 2016c. Lactose in milk replacer can partly be replaced by glucose, fructose, or glycerol without affecting insulin sensitivity in veal calves. J. Dairy Sci. 99:3072-3080.

Roy, J. H. B., I. J. F. Stobo, H. J. Gaston, and J. C. Greatorex. 1970. The nutrition of the veal calf 2 . The effect of different levels of protein and fat in milk substitute diets. Br. J. Nutr. 24:441-457.

Sarraseca, A., E. Milne, M. J. Metcalf, and G. E. Lobley. 1998. Urea recycling in sheep: Effects of intake. Br. J. Nutr. 79:79-88.

Schäff, C. T., J. Gruse, J. Maciej, M. Mielenz, E. Wirthgen, A Hoeflich, M. Schmicke, R. Pfuhl, P. Jawor, T. Stefaniak, and H. M. Hammon. 2016. Effects of feeding milk replacer ad libitum or in restricted amounts for the first five weeks of life on the growth, metabolic adaptation, and immune status of newborn calves. PLoS One 11:e0168974.

Schroeder, G. F., E. C. Titgemeyer, M. S. Awawdeh, J. S. Smith, and D. P. Gnad. 2006. Effects of energy source on methionine utilization by growing steers. J. Anim. Sci. 84:1505-1511.

Stanley, C. C., C. C. Williams, B. F. Jenny, J. M. Fernandez, H. G. Bateman Ii, W. A. Nipper, J. C. Lovejoy, D. T. Gantt, and G. E. Goodier. 2002. Effects of feeding milk replacer once versus twice daily on glucose metabolism in Holstein and Jersey calves. J. Dairy Sci. 85:2335-2343.

van den Borne, J. J. G. C., S. J. J. Alferink, M. J. W. Heetkamp, A A. A. Jacobs, M. W. A. Verstegen, and W. J. J. Gerrits. 2012 Asynchronous supply of indispensable amino acids reduces protein deposition in milk-fed calves. J. Nutr. 142:2075-2082.

van den Borne, J. J. G. C., G. E. Lobley, M. W. A. Verstegen, J M. Muijlaert, S. J. J. Alferink, and W. J. J. Gerrits. 2007. Body fat deposition does not originate from carbohydrates in milk-fed calves. J. Nutr. 137:2234-2241.

van den Borne, J. J. G. C., J. M. A. J. Verdonk, J. W. Schrama, and W. J. J. Gerrits. 2006a. Reviewing the low efficiency of protein utilization in heavy preruminant calves-A reductionist approach. Reprod. Nutr. Dev. 46:121-137.

van den Borne, J. J. G. C., M. W. A. Verstegen, S. J. J. Alferink, R. M. M. Giebels, and W. J. J. Gerrits. 2006b. Effects of feeding frequency and feeding level on nutrient utilization in heavy preruminant calves. J. Dairy Sci. 89:3578-3586.

van den Borne, J. J. G. C., M. W. A. Verstegen, S. J. J. Alferink, F. H. M. Van Ass, and W. J. J. Gerrits. 2006c. Synchronizing the availability of amino acids and glucose decreases fat retention in heavy preruminant calves. J. Nutr. 136:2181-2187.

Van der Togt, P. L., and W. J. J. Gerrits. 1998. Validatie van een groeimodel bij vleeskalveren van $80-240 \mathrm{~kg}$ [in Dutch]. in Rapport voor Productschap voor Veevoeder. Wageningen, the Netherlands. 
Vicari, T., J. J. G. C. van Den Borne, W. J. J. Gerrits, Y. Zbinden, and J. W. Blum. 2008a. Postprandial blood hormone and metabolite concentrations influenced by feeding frequency and feeding level in veal calves. Domest. Anim. Endocr. 34:74-88.

Vicari, T., J. J. G. C. van Den Borne, W. J. J. Gerrits, Y. Zbinden, and J. W. Blum. 2008b. Separation of protein and lactose intake over meals dissociates postprandial glucose and insulin concentrations and reduces postprandial insulin responses in heavy veal calves. Domest. Anim. Endocr. 34:182-195.

Webb, L. E., C. G. van Reenen, H. Berends, B. Engel, I. J. M. de Boer, W. J. J. Gerrits, and E. A. M. Bokkers. 2015. The role of solid feed amount and composition and of milk replacer supply in veal calf welfare. J. Dairy Sci. 98:5467-5481.

Whittemore, C. T., and R. H. Fawcett. 1976. Theoretical aspects of a flexible model to simulate protein and lipid growth in pigs. Anim. Prod. 22:87-96.

Yunta, C., M. Terré, and A. Bach. 2015. Short- and medium-term changes in performance and metabolism of dairy calves offered different amounts of milk replacers. Livest. Sci. 181:249-255.

Zanton, G. I., and A. J. Heinrichs. 2008. Analysis of nitrogen utilization and excretion in growing dairy cattle. J. Dairy Sci. 91:15191533 . 